\title{
Innovative HVAC System Using an Integrated Greenhouse for a Virtual Low Energy Office Building
}

\author{
Catalin Lungu, ${ }^{1, *}$, and Florin Baltaretu ${ }^{2}$ \\ ${ }^{1}$ Technical University of Civil Engineering Bucharest, STHPA Department, Bd. Pache Protopopescu nr. 66, Bucharest, Romania \\ ${ }^{2}$ Technical University of Civil Engineering Bucharest, Department of Thermal Sciences, Bd. Pache Protopopescu nr. 66, Bucharest, \\ Romania
}

\begin{abstract}
In this paper the authors describe a HVAC innovative system using an integrated greenhouse for heating and cooling an office building. The ventilation system allows natural (night) or mechanical ventilation and the passive cooling during the summer, including cold storage in the building structure and the PCM plywood and the refrigeration energy use during the day. Natural ventilation occurs when the wind or the Venturi effect, created by the " hat " that supports the photovoltaic panels, is strong enough; otherwise, a variable speed exhaust fan mounted on top of the building is used. The plants inside the greenhouse can produce $\mathrm{O}_{2}$ under certain conditions necessary for refreshing the ventilation air. The environment of the greenhouse allows air humidification naturally, without the use of humidifiers. If the greenhouse is sufficiently insulated in winter, it can be used in the ventilation process: the air intake from offices through the greenhouse, humidified and enriched in $\mathrm{O}_{2}$ (premixed, if necessary, with fresh air) reaches the general air treatment unit, and then sent back. The process is similar in the summer, but without recirculation, due to the humidity of the air extracted from offices. Stale air humidification enhances the thermal transfer process from the desiccant collector.
\end{abstract}

\section{Introduction}

Large buildings equipped with heating, ventilation and air conditioning (HVAC), data centers, and a myriad of sensors and wireless communication devices are complex systems whose operation includes multiphysics and multi-scale effects. Those buildings clearly offer tremendous potential for reducing our demand for energy and its concomitant carbon emissions [1] [2] [3].

Building systems are dynamically uncertain with respect to both the energy load and the environment, with dramatic changes in:

- the number of occupants in the building,

- their energy demand, and

- ambient weather conditions..

The present paper deals with the design of a particular green, bio-climatic, nearly zero energy building (nZEB).

The building will have the main destination as headquarters for an advanced research and innovation center, and will include different laboratories.

Other targets consist in:

- the BREEAM outstanding building label (the first one in Romania);

- the use of the natural resources in and out;

- the achievement of an innovative building technology "live exhibition";

- the self-funding capacity after construction.
The paper presents the concepts used in the design of the building, some technical details about architecture, structure and HVAC and related building systems. Advantages and disadvantages of such a project are also emphasized, as well as legal aspects on European and national levels.

\section{Major Technical Details and Building Characteristics}

The main technical characteristics of the RO-nZEB building, which ensure its unicity at a global level, are the following:

- nZEB BUILDING (nearly-zero-energy-building) according to European and national legislation, with energy consumption nearly zero, making it very energy efficient and at the same time equipped for plants using renewable energy sources, including monitoring systems and $24 \mathrm{~h} / 24 \mathrm{~h}$ energy consumption and production display (through BMS system).

- GREEN BUILDING evaluated according to official international BREEAM (Building Research Establishment Environmental Assessment Method) procedure and marked with the qualifier "OUTSTANDING", following 10 major criteria and over $50 \mathrm{sub}$-criteria on the health and comfort of occupants, energy efficiency, pollution and environmental impact etc.

\footnotetext{
* Corresponding author: clungu@yahoo.com
} 
- BIOCLIMATIC BUILDING, both by integrating in its structure a greenhouse for plants designed to help air filtration required for ventilation and partially offsetting $\mathrm{CO} 2$ emissions by occupants of the building, and by managing the technical systems of the building, so that a larger part of the environmental resources (water, sun, wind, soil) be exploited to the advantage of the building's energy status and comfort of occupants.

\subsection{Major Technical Details of the Building}

The major technical details of the building are presented in Table 1.

Table 1. Major Technical Details of the Building.

\begin{tabular}{|l|l|}
\hline \multicolumn{1}{|c|}{ Margin } & \multicolumn{1}{c|}{ mm } \\
\hline $\begin{array}{l}\text { Building } \\
\text { Destination }\end{array}$ & laboratories for R\&D with offices \\
\hline Height & B+GF+4E+5E withdrawn \\
\hline $\begin{array}{l}\text { Gross Internal } \\
\text { Area }\end{array}$ & $\begin{array}{l}2.000 \text { sqm } \\
(250+\text { sqm average/floor })\end{array}$ \\
\hline $\begin{array}{l}\text { Building } \\
\text { Structure }\end{array}$ & $\begin{array}{l}\text { - mixed metal-concrete (rigid } \\
\text { structure }) \\
\bullet \text { ventilated double-skin façade } \\
\bullet \text { TABS }\end{array}$ \\
\hline $\begin{array}{l}\text { Heating \& } \\
\text { Cooling }\end{array}$ & $\begin{array}{l}\bullet \text { air \& water }+ \text { PCM } \\
\bullet \text { night free cooling }\end{array}$ \\
\hline $\begin{array}{l}\text { Green } \\
\text { features }\end{array}$ & $\begin{array}{l}\bullet \text { green roof 5th floor } \\
\bullet \text { embedded greenhouse }\end{array}$ \\
\hline
\end{tabular}

The energy consumption of the building, simulated with TRNSYS, will stay below $50 \mathrm{kWh} /\left(\mathrm{m}^{2}\right.$ year $)$ (primary energy) and the renewables will provide up to $100 \%$ of the total consumption, meeting the nZEB national conditions. In some periods of the year ROnZEB could deliver energy to other near buildings, becoming an "energy plus" building.

\subsection{Green Building Characteristic}

A building evaluated as "green" according to internationally accepted procedures [4], provides the occupants guarantees regarding the indoor environmental quality and the building itself (building materials environmentally responsible, efficient use of resources etc.).

The BREEAM assessment method (Environmental Assessment Method Building Research Establishment) is the most widely used green building rating system in the world, with over 250,000 buildings certified and over $1,000,000$ registered buildings to be certified from 1990 to present. In Romania there are more than 50 certified green building using BREEAM assessment method and can be identified in the online archive www.greenbooklive.com.

The RO-nZEB building will be evaluated with the BREEAM International Bespoke 2013 scheme. Following the pre-assessment, a score of $92.97 \%$ was obtained, thereby falling into the category BREEAM OUTSTANDING, the only existing one at national level (only $1 \%$ of the buildings evaluated globally with BREEAM method as "green" received the maximum OUTSTANDING rating).

Table 2. Loans obtained by the RO-nZEB building during the BREEAM pre-assessment

\begin{tabular}{|c|c|c|c|c|c|}
\hline $\begin{array}{c}\text { BREEAM } \\
\text { Criterion }\end{array}$ & $\begin{array}{ll}\frac{0}{0} & \\
\frac{\pi}{\pi} & 0 \\
\frac{\pi}{\pi} & 0 \\
\frac{0}{<} & 0\end{array}$ & 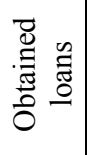 & 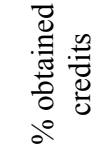 &  & 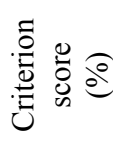 \\
\hline $\begin{array}{l}\text { Manageme } \\
\mathrm{nt}\end{array}$ & 23 & 23 & 100.00 & 12.00 & 12.00 \\
\hline $\begin{array}{l}\text { Health and } \\
\text { Welfare of } \\
\text { Occupants }\end{array}$ & 13 & 13 & 100.00 & 14.00 & \multirow[b]{2}{*}{15.00} \\
\hline $\begin{array}{l}\text { Health and } \\
\text { Welfare of } \\
\text { Occupants } \\
\text { - Natural } \\
\text { Disasters }\end{array}$ & 0 & 0 & 0.00 & 1.00 & \\
\hline Energy & 24 & 23 & 95.83 & 18.50 & 17.73 \\
\hline Transport & 9 & 9 & 100.00 & 5.00 & 5.00 \\
\hline Water & 9 & 8 & 88.89 & 6.00 & 5.33 \\
\hline Materials & 11 & 10 & 90.91 & 12.00 & 10.91 \\
\hline Waste & 6 & 4 & 66.67 & 10.00 & 6.67 \\
\hline $\begin{array}{l}\text { Land use } \\
\text { and } \\
\text { ecology }\end{array}$ & 10 & 7 & 70.00 & 10.00 & 7.00 \\
\hline Pollution & 9 & 8 & 88.89 & 6.00 & \multirow[b]{2}{*}{10.33} \\
\hline $\begin{array}{l}\text { Pollution - } \\
\text { Rainwater } \\
\text { drainage }\end{array}$ & 5 & 5 & 100.00 & 5.00 & \\
\hline Innovation & 10 & 3 & 30.00 & 10.00 & 3.00 \\
\hline TOTAL & & & & & 92.97 \\
\hline
\end{tabular}

\subsection{Bio-Climatic Building Characteristic}

A bioclimatic building is a building that integrates passively the natural resources in the vicinity environment to ensure the optimal comfort conditions for the building's occupants. The natural resources category includes the sun, vegetation, wind, rain etc.

The passive integration of these resources is achieved through the passive construction elements, such as double-ventilated facades, integrated greenhouses, 
automated openings wrapped in envelope for natural ventilation, inertial walls and floors incorporating PCM (Phase Change Materials) and TABS (Thermaly Activated building structure), solar tubes for natural lighting.

The RO-nZEB building will be a bioclimatic building through:

- the use a greenhouse, built over the height of the building, which will contribute to the air filtration necessary for ventilation and partially offset the $\mathrm{CO} 2$ emissions of the building's occupants;

- the double-glazed facades using natural or mechanical ventilation;

- the use of night ventilation for passive cooling of the building during the night;

- the use of phase change materials for energy storage necessary for cooling/heating of the building;

- the use of solar tubes for lighting;

- the use of geothermal heat pumps for cooling/heating the building using mainly radiation by embedding heat pipes in the concrete floors of the building;

- the use of photovoltaic panels;

- the use of wind microturbines.

\subsection{Architectural concepts}

The architectural concepts integrates the major characteristics nZEB + green building + bioclimatic building using the concepts of protection / intersection / shield / transparency [5]. In this view, the building has an opaque façade on the $\mathrm{N}$ side and double skinned facades on $\mathrm{E}, \mathrm{W}$ and $\mathrm{S}$ sides. It also integrates a greenhouse, acting as a buffer zone, but also in the heat and mass exchanges [6]. The air purification is made by using high tech filters, but also using natural filters.

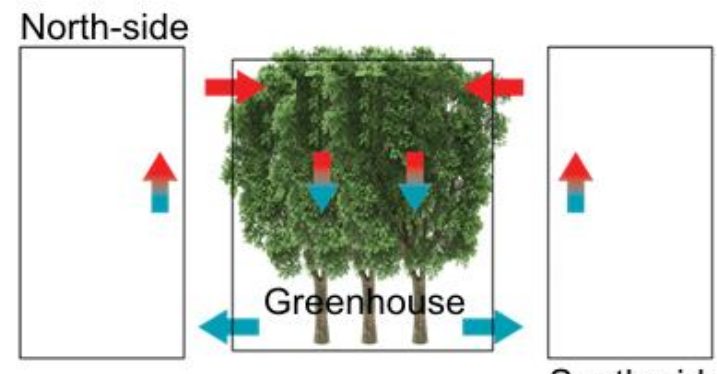

South-side

Fig. 1. Greenhouse integration

\section{Engineering concepts and figures}

The main engineering concepts of the RO-nZEB concern electric energy conceptual design, building management system and HVAC plant operation and control.

\subsection{The electric power sources provided in the building}

There are multiple power sources for the RO-nZEB building.



Fig. 2. Arhitectural concept

- Cogeneration system

The cogeneration system consists of a heat engine and a maximum $200 \mathrm{kVA}$ electric generator that will be able to partially provide the electrical and thermal load of the building.

- Photovoltaic panels

Two areas where photovoltaic panels will be mounted are provided.

Thus, the first area is the roof of the building, where two photovoltaic concentrators will be mounted, concentrators that will orient themselves by the sun's position. These hubs will provide a maximum power of $29,4 \mathrm{~kW}$ each.

The second area where solar panels will be mounted is located outside the building, mounted on an area of approximately $120 \mathrm{sqm}$. The photovoltaic panels will be fixedly mounted, and will ensure a maximum output of $20 \mathrm{~kW}$.

- Wind turbines

The building will be equipped with three vertical wind turbines mounted on the green terrace of the building. These turbines will provide a maximum power of $3 \mathrm{~kW}$ each.

- Transformer unit

The building will have a source of power supply consisting of the $400 \mathrm{kV}$ transformer station that will be able to take over the load of building.

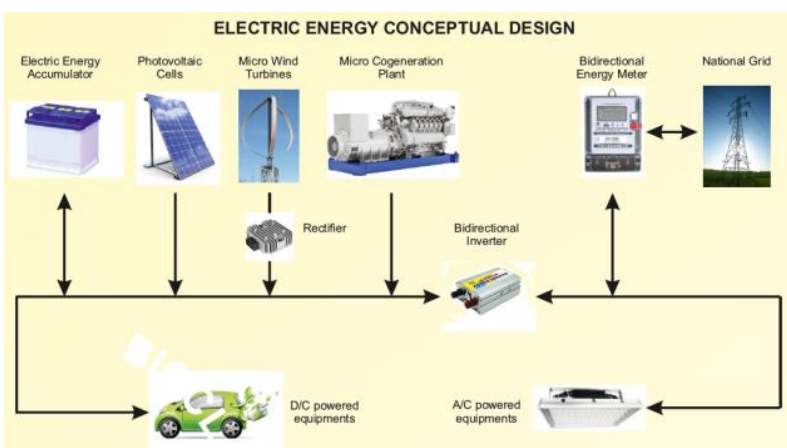

Fig. 3. Electric energy conceptual design 


\subsection{The Building management system - BMS}

BMS system architecture is based on four levels:

- Level 1 - level of sensors and actuators

- Level 2 - level of the local control units

- Level 3 - level of integration units

This unit will act as an interface between the main surveillance unit and local units. It will also manage and integrate communications with third party of the system.

- Level 4 - system management level

The local control equipment will communicate with the integration systems through a BACnet MS/TP type of network.

The integration equipment will communicate with the central unit via a BACnet IP type of network. The metering system will be connected to the building's BMS system.

\section{HVAC Systems}

\subsection{Central heating/air-conditioning}

The main equipment of the central heating components are:

- Geothermal reversible heat pump of 75-100 kW that extracts/inserts heat from/in soil through 14 wells drilled to an average depth of $110 \mathrm{~m}$;

- Cogeneration engine of about 50-80kW (35-50kW electric) whose power is adjusted depending on the electricity demand of the heat pump, as the heat generated is used to regenerate the desiccant substance from the collector of the plant for handling and preparing domestic hot water;

- The general air handling unit in summer/winter, with desiccant rotary collector;

- Circulation pumps for sources of heat and cold;

- Buffer tank for heat pump of min. 1000 liters;

- Boiler for domestic hot water of min. 400 liters;

- Water treatment plant (water softening);

- Expansion modules for controlling the pressure in the heating/air-conditioning system.

Each plant will be monitored through the building's BMS system in terms of energy (electric or natural gas consumption), but also in various modes of operation to use (summer, winter, stationary, dynamic).

\subsection{Distribution of heating/cooling pipes}

From the heat pump, the heating/refrigeration power distribution is done through the same pipeline to consumers, through TABS (thermo-activation system of concrete building) - a system of radiant floor circuits embedded in concrete floors.
Each floor of the building (ground-floor - 4th floor) is divided into $4+1$ independent areas in terms of heat and set, or separately metered (1 area of common spaces and four areas in the lab). TABS takes only sensible heat from the building during the summer, namely which compensates for heat losses through transmission in winter.

The temperature control is based on a room thermostat entering the equipment supply like a remote control which can set the temperature, air velocity and operating programme.

During the summer, since it is necessary to avoid condensation on the surfaces of ground and floors, the chilled water temperature from the heat pump is high, not allowing to take the air's latent heat from the building or exterior (no dehumidification occurs).

It is therefore imperative that in the general air handling plant be used a desiccant cooling dehumidification system whose regeneration is done with heat coming in summer from the cogeneration engine.

The heating/air-conditioning allows a local correction of the interior parameters of comfort from laboratories through mini treatment plants mounted in the ceiling of each floor of the building.

\subsection{HVAC design assumptions/directions}

To determine solutions for heating, air conditioning and ventilation, the following were taken into account:

- for calculating external parameters, according to Romanian standards SR 1907-2014, for winter te=$15^{\circ} \mathrm{C}$ (for the city of Bucharest);

- from STAS 6648-2014 for summer, with degree of assurance of $98 \%$, te $=+35^{\circ} \mathrm{C}$.

- occupation of premises: 40 researchers.

- values that characterize the building operation during:

- winter, $150 \mathrm{~kW}$, out of which $110 \mathrm{~kW}$ used to treat fresh air;

- summer, $203 \mathrm{~kW}$, out of which $31 \mathrm{~kW}$ used to treat fresh air.

- maximum flow rate of fresh air is $8900 \mathrm{~m} 3 / \mathrm{h}$.

- using PCM as gypsum plates used to cover the concrete pillars and ceilings of the building leads to a reduction of the maximum cold power with minimum $15 \%$

- $(26 \mathrm{~kW})$ of the power sensitive during the summer.

- using a heat recovery in the general air handling plant can lead to a decrease of the heating power of approx. $100 \mathrm{~kW}$ in winter and approx. $25 \mathrm{~kW}$ in summer.

The building will be equipped with a grey wastewater reuse system and with a reuse of rainwater. Grey wastewater and rainwater will be used for spraying green areas or for supplying the reservoirs for washing the toilet tanks. 


\subsection{Free night cooling (summer)}

The ventilation system allows natural night or mechanical ventilation of the heat and its passive cooling during the summer, including cold storage in the building structure and the PCM plywoods and refrigeration energy use during the day.

Natural ventilation occurs when the Venturi effect created by the " hat " that supports the photovoltaic panels is strong enough (the wind speed sensor automatically opens the slots valves created in the " hat ») structure).

In the absence of wind and the Venturi effect a variable speed exhaust fan mounted on top of the building/greenhouse will be used.

In both cases the free-cooling ventilation is produced by air entering through automated openings of the double-glazed facade and through the openings in the greenhouse integrate in the building.

The fan at the top of the building has the role of producing ventilation and cooling of the glass facade when temperatures between the 2 glazings grow over the presented value.

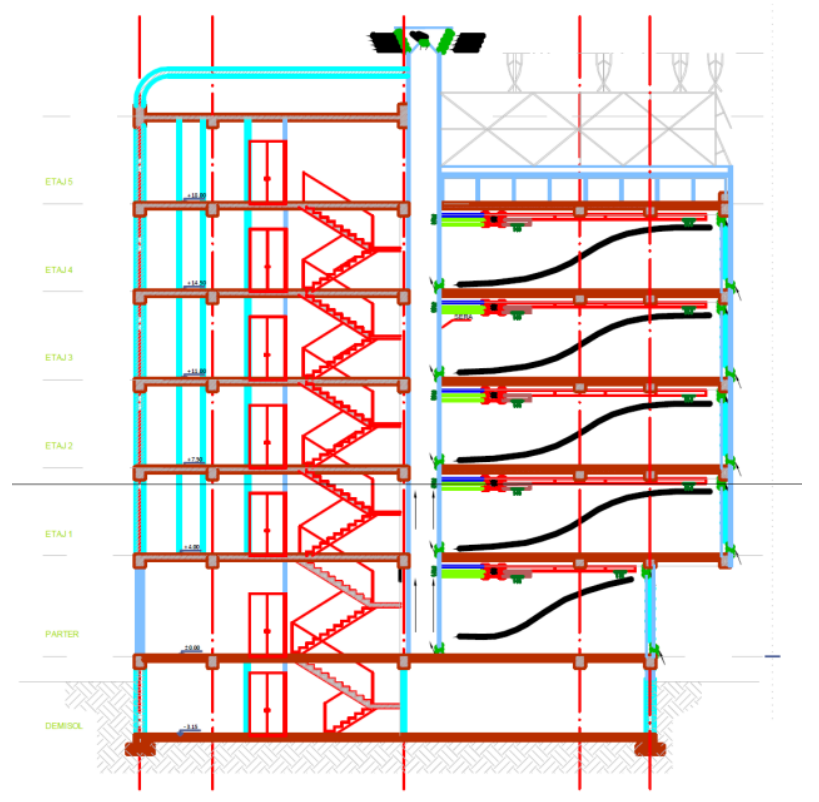

Fig. 4. Night free cooling

\subsection{Ventilation with recirculation $0 . . .100 \%$ (summer/winter)}

The plants of the greenhouse can produce $\mathrm{O}_{2}$ under certain conditions necessary for freshening the air needed for the total ventilation of the building.

The environment of the greenhouse naturally allows air humidification, without the use of adiabatic or isothermal humidifiers.
If the greenhouse is sufficiently insulated in winter, it can be used in the ventilation process. Thus, the air intake from laboratories through the greenhouse, humidified and enriched in $\mathrm{O}^{2}$, reaches the general air treatment plant where it heats (premixed, if necessary, with fresh air from outside), and then sent back to laboratories, through air treatment local units (local AHU).

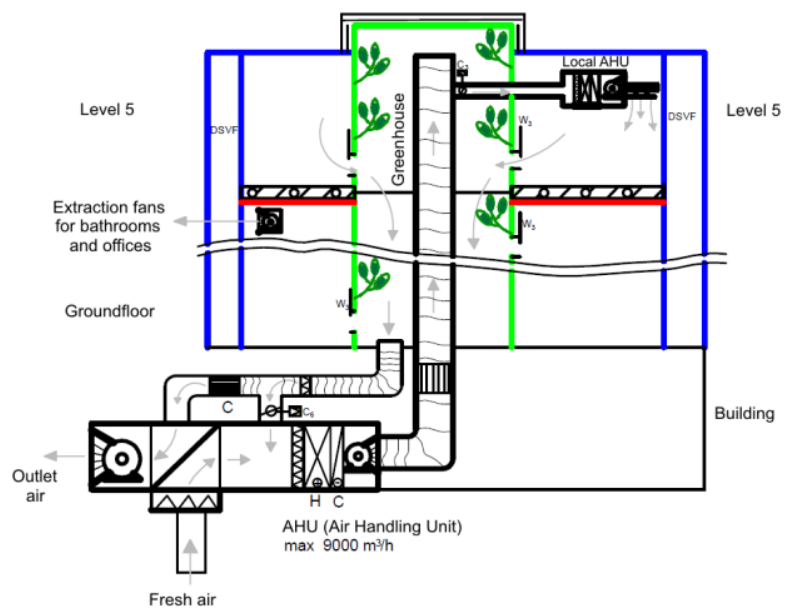

Fig. 5. HVAC using mechanical ventilation and AHUs

The process is similar in the summer, but without recirculation due to the humidity of the air extracted from laboratories. Stale air humidification enhances the thermal transfer process from the desiccant collector.

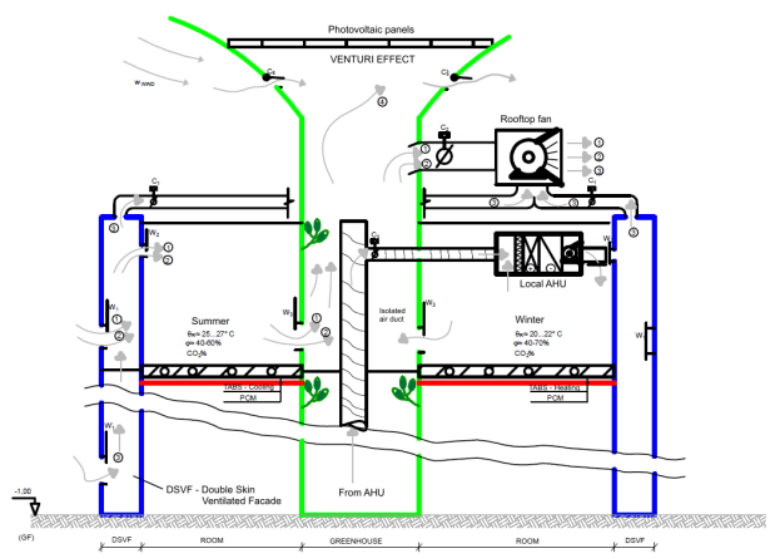

Fig. 6. HVAC using natural ventilation and Venturi efect

\subsection{The air discharge from toilets and offices}

All bathrooms and offices are equipped with vertical columns of air to evacuate foul air in a centralized way. For the bathrooms' ventilation, an air extraction facility was set, facility that would provide 6 ventilation exchanges/hour. The air discharge is performed using bathroom fans with check valves, mounted on vertical columns, in each bathroom. They are activated from the light switch on for the bathroom. 


\subsection{HVAC control strategy}

The control strategy, shown in figure 7 (cooling mode) and in figure 8 (heating mode) take into account the fact that the fresh air flow rate varies upon $\mathrm{CO}_{-} 2$ as a function of the number of people. The $W_{1} / W_{2} / W_{3}$ are $\mathrm{P}$ (proportional) regulated.



Fig. 7. Cooling mode control strategy

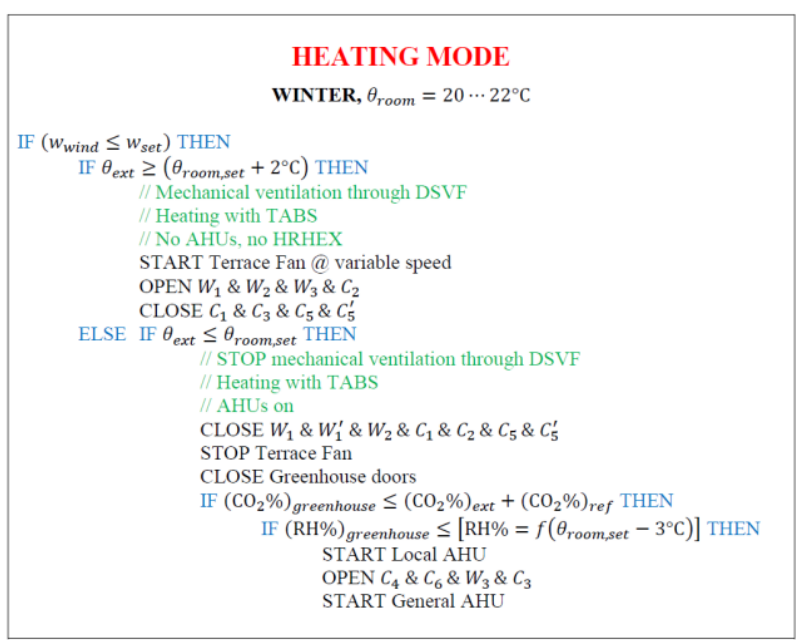

Fig. 8. Heating mode control strategy

\section{Conclusions}

The RO-nZEB building is the first Romanian nZEB public building, the first Romanian bioclimatic building, and the first Romanian "outstanding" BREEAM building, aiming:

- the building will be used as offices and laboratories for advanced research in the building sector (materials and installations)

- integral site renovation and building technology live-exhibition

- self-funding after construction - Promotion of construction companies (LED panel on the facade)

- big contribution to the development of the sustainable built environment

- integration of young researchers/integration of coming-back researchers.

The paper described an HVAC innovative system using an integrated greenhouse for heating and cooling for the RO-nZEB building, including main engineering concepts and figures, as well as the control strategy.

\section{References}

1. Directive 2010/31/EU of the European Parliament and of the Council of 19 May 2010 on the Energy Performance of Buildings (Recast).

2. Law no. 372/13.12.2005 regarding the transposition of the EPBD into Romanian law, on energy performance of buildings, 2013 (republished).

3. Nearly Zero Energy Buildings (nZEB) Romania Plan to increasing the number of nearly zero-energy buildings, the Romanian Ministry of Regional Development and Public Administration, 2014

4. BREEAM International New Construction Technical Manual, 2013

5. F. Barbolini, P. Cappellacci, L. Guardigli, A design strategy to reach nZEB standards integrating energy efficiency measures and passive energy use, 8th International Conference on Sustainability in Energy and Buildings, SEB-16, 11-13 September 2016, Turin, Italy, Energy Procedia 111 (2017) 205 - 214.

6. S. Modirrousta, H. Boostani, Analysis of Atrium Pattern, Trombe Wall and Solar Greenhouse on Energy Efficiency, International Conference on Sustainable Design, Engineering and Construction, Procedia Engineering 145 (2016) 1549 - 1556. 